\title{
IMAGENS DE ONTEM E DE HOJE
}

B asta ligar o aparelho de televisão, folhear uma revista ou andar pelas ruas da cidade para darmo-nos conta da quantidade de imagens que disputam nossos olhares. $O$ marketing avassalador que caracteriza a atual sociedade de consumo vende, antes de tudo, imagens; imagens que fundem e confudem coisas com gente e gente com coisas. Enquanto produtos se revestem das qualidades humanas, os homens esmeram sua imagem revestindo-se de produtos. $O$ que vale é produzir uma trama visual capaz de enredar o consumidor.

Mas, paralelamente a esse jogo de maquiagem que atua a partir de fora e trabalha a exterioridade, a sociedade exculpe, a partir de dentro de si mesma, outras imagens, forjadas no embate das relações sociais, projetando-as na tela do imaginário social.

É na esteira dessas imagens que transita o presente número de Travessia.

Cada artigo, com sua autonomia, e a partir de referenciais os mais variados-imprensa, poesia, mísica, literatura..., - vai traçando como que involuntariamente uma cronologia de imagens da migração e do próprio migrante.

Os anos que antecedem a virada do século XIX, mais precisamente quando da passagem do trabalho escravo para o trabalho livre, estão em foco na análise da noção de estrangeiro, feita a partir do imigrante negro que, curiosamente, deixa de ser visto como brasileiro e passa a ser encarado como africano.

As primeiras décadas do presente século estão presentes nas imagens que os imigrantes, sobretudo europeus, evocam no poeta Mário de Andrade; inicialmente acalentando o sonho de uma integração harmoniosa, para, em seguida, com oadvento de novas levas, provocar a sensação de quem se depara com um "dilúvio de penetras".

O periodo dos anos 30-40, a chamada 'Era Vargas', ganha destaque no estudo dos discursos, em nivel oficial e literário, que colocam em causa as migrações nordestinas, as quais, estigmatizadas, comportam imagens que oscilam entre atitudes de aceitação e rejeição.

As décadas de 50-60 são contempladas do ponto de vista da música popular brasileira, a qual traduz em som e versos as imagens que marcam a saga dos retirantes, repleta de ilusões e desilusões.

À migração consolidada de nordestinos em São Paulo, dedica-se um artigo que busca entender o processo de interiorização por parte dos próprios migrantes, de imagens estereotipadas de si mesmos.

O momento atual, marcado por crescente tendência de discriminação, ganha espaço no olhar crítico às abordagens que o livro didático de geografia traz em relação ao migrante.

Partindo de outro veio, o do surgimento da televisão no Brasil, veículo número um na difusão de imagens, a tematização da mediação cultural que se processa entre a produção televisiva e as classes populares.

Por fim, a seção debate, provocando concepções que norteiam olhares acerca do universo de camponeses-migrantes temporários do Vale do Jequitinhonha-MG.

Dirceu Cutti 